\title{
NEW CHALLENGES FOR THE LEGAL EDUCATION IN LATVIA
}

\author{
Janis Grasis \\ Rīga Stradiņš University, Latvia
}

\begin{abstract}
The Cabinet of Ministers of the Republic of Latvia adopted Regulation No. 46 "Procedures for the National Uniform Professional Legal Qualification Examination" on January 15, 2019. These rules will apply to students who started studies in the course of the professional master's study programme at the autumn semester of 2019; therefore, the first exam will be in 2021. The qualification examination will have the following parts: (1) the theoretical part in which detailed answers to 15 questions are provided in writing; (2) the practical part in which five practical tasks (case -studies) are dealt with in writing. Novelty of the research: this is one of the newest academic research concerning the mentioned examination which is something new for Latvian legal education, trying to make comparision with analogous Uniform Examination in Germany. The research aim is to analyse critically the new regulations and how will it affect existing master programmes of law in the universities of the Republic of Latvia. Descriptive, analytical and deductive-inductive research methods are used. Legal acts, policy planning documents and different reports were reviewed and analyzed, and subsequently conclusions and recommendations were made. On the one hand the introduction of the mentioned examination could contribute to increasing motivation of students, to acquiring deeper and more sustainable knowledge in law study programmes, which can be assessed positively. However, it is not clear what the criteria are, the content of what the requirements will be for the methodology for evaluating the National Uniform Professional Legal Qualification Examination, which is approved by the commission itself. This could be a risk element for transparency and uniform understanding during the development of examination questions and in the evaluation process of examination answers.
\end{abstract}

Keywords: education, lawyer, professional standard, Uniform Qualification Examination.

\section{Introduction}

The lawyer's profession involves both providing legal aid to others persons in the protection of their rights and taking a nationally important positions (including like judges, prosecutors etc.), so it is important that the demands of a lawyer qualifications are high enough. It is particularly important in the legal professions, to be able to combine theoretical knowledge and values with practical skills, to be able to deal with legal language as a special tool in the hands of a lawyer. Just know government of the Republic of Latvia would like to raise competence level of the lawyer's. The research aim of the present article is to analyse critically the new regulation on procedures for the National Uniform 
Professional Legal Qualification Examination and how will it affect existing master programmes of law at the universities of the Republic of Latvia. The Cabinet of Ministers of the Republic of Latvia adopted Regulation No. 46 "Procedures for the National Uniform Professional Legal Qualification Examination" on January 15, 2019, and these rules will apply to students who started studies 2019 in the course of the professional master's study programme at the autumn semester of 2019. Descriptive, analytical and deductive-inductive research methods are used. Legal acts, policy planning documents, literature and different reports were reviewed and analyzed, and subsequently conclusions and recommendations were made.

\section{Advantages and unclear question of the new regulation}

\section{Literature review}

Theme of present article is not so much discussed in the academic literature. Recently one academic article under title "Trends of Legal Education Reform in Latvia" was published by Artūrs Gaveika (Gaveika, 2018). He concluded that "The content of the Single lawyer's professional qualification exam approved in December 2017 is not specific but examination methodology is totally unacceptable from the pedagogical and didactic point of view, because it is contrary to all higher education institutions agreed principles and in practice proven test-taking principles. Unfortunately, the objections of the Student Association of Latvia and several universities in this regard were not taken into account” (Gaveika, 2018). This article was continuation of previous research by Artūrs Gaveika (Gaveika, 2017). Dean of the Faculty of Law of Rīga Stradiňš university Andrejs Vilks has published the article "New challenges for Legal education" (Vilks, 2019). He comes to the conclusion that "The introduction of the National Uniform Professional Legal Qualification Examination determines the necessity to transform the study process, to make changes in the study courses to be implemented, to supplement the requirements in the sub-branches of law, where students' knowledge in a single examination will be checked. Currently, it is too early to conclude whether the introduction of a National Uniform Professional Legal Qualification Examination will increase the quality of legal education, and graduates of legal science study programmes will increase their knowledge and skills in jurisprudence" (Vilks, 2019). So, mentioned three academic articles are a very critical towards the changes concerning National Uniform Professional Legal Qualification Examination. Also Kitija Bite, in her thesis, on the one hand supports the state's efforts to assess the education and quality of professional qualifications acquired in a higher education institution; on the other hand the examination is intended after the acquisition of a master's study programme (for the acquisition of qualifications), but the knowledge and 
skills to be tested, are fundamental issues of law which usually studied in bachelor programme (Bite, 2018). According to the opinion of dean of the Law Faculty of the Biznesa augstskola "Turība" Jānis Načisčionis, the Examination is not a quality indicator. The quality of law studies shall be verified and provided by an accreditation process performed by the Academic Information Centre (Načisčionis, 2019). On the other hand some articles in the professional journals support the reforms. For example, Laila Medina and Inta Salinieka underline that the aim of the legal examination is to increase the quality of legal education and to ensure the acquisition of the knowledge, skills and competences of all trained lawyers, at least at the level of basic knowledge, by establishing uniform requirements for obtaining the professional qualifications of a lawyer. According to their opinion, the following indicators show the benefits of the single legal exam:

1) higher quality of legal education;

2) uniform requirements for obtaining the professional qualification of a lawyer;

3) uniform examinations of students who acquire professional qualifications, knowledge, competences and skills of a lawyer;

4) the persons who have obtained the professional qualification of a lawyer have certified the basic knowledge necessary for the lawyer (Medina \& Salinieka, 2020). Novelty of the research: this is one of the newest academic research concerning the mentioned examination which is something new for Latvian legal education. The author also trying to make comparision with analogous Uniform Examination in Germany.

\section{Methodology of the research}

The research object of the article is relations between universities and state within educational law concerning National Uniform Professional Legal Qualification Examination. The tasks of the research are the following: 1) to make brief general characteristics of the new regulation; 2) to analyse practical problems arising from the new regulation; 3) to elaborate suggestions to overcome shortcomings in the practise. Descriptive, analytical and deductive-inductive research methods are used. Legal acts, policy planning documents, literature and different reports were reviewed and analyzed, and subsequently conclusions and recommendations were made. The article is dedicated to issues and perspectives of legal education reforms and how requirements of regulation in the context of the topic will affect study programmes in the Republic of Latvia.

\section{Research results}

In order to perform National Uniform Professional Legal Qualification Examination (hereinafter - Examination), Minister of Justice shall, at least once a year, approve a commission of 45 members (Valsts vienotā jurista profesionālās 
kvalifikācijas eksāmena kārtība, 2019, article 9). After the invitation of the Minister of Justice to participate in the commission, universities shall nominate a specified number of representatives indicated by the Minister of Justice in proportion to the predictable number of students who will take a qualification examination, but not less than one representative. The Prosecutor General's Office and the professional organisations representing the legal sector - Latvian Council of Sworn Advocates, Latvian Council of Sworn Notaries, Latvian Council of Sworn Bailiffs, Latvian Union of Judges - shall, at the invitation of the Minister of Justice, nominate a number of representatives of the commission determined by the Minister of Justice in proportion to the number of the institutions referred to and the information regarding the number of such institutions. Representatives shall be submitted to the Minister for Justice of approval. The commission of each institution shall have the same number of representatives (Valsts vienotā jurista profesionālās kvalifikācijas eksāmena kārtība, 2019, article 12). The most interesting legal aspects concerning Examination commission are the following: the members of the Examination commission shall elect, by a simple majority, the chairperson of the commission and the vice-chairperson of the commission. The chairperson of the commission and the Vice-Chair of the Commission may not be a representative of the university, as well as a representative of the organisation representing the legal sector, who participates in the implementation of the study programme in university (Valsts vienotā jurista profesionālās kvalifikācijas eksāmena kārtība, 2019, article 15). Specific questions of the Examination shall be determined by the chairperson of the commission, the vice-chairperson of the commission and the representatives of the industry from the Prosecutor General's Office and the professional organisations representing the legal sector. In determining specific issues of the Examination, representatives of organisations representing the legal sector who participate in the implementation of the study programme in higher education shall not participate in the meeting of the commission (Valsts vienotā jurista profesionālās kvalifikācijas eksāmena kārtība, 2019, article 30). What is it means in practice? Universities are fully excluded from participation in the decision process concerning questions of examinations. There is not real connection between study programmes of the Universities and the Examination. The authors of the present regulation of Examination always referred to the practice of Germany; for example, chairperson of the Saeima (Parliament of Latvia) Legal Affairs Commission Gaidis Berzins commented that "Such an examination also exists in other European countries, such as Germany, and its introduction will raise the qualifications of Latvian lawyers'. During the debates in Latvian Parliament (Saeima) Gaidis Berzins indicated that each university evaluate the theoretical knowledge and skills of the students in order to grant a State-recognised university diploma with the qualifications of a lawyer at its discretion. As a result, the diploma is obtained by students who have been 
subjected to relatively higher requirements for obtaining a diploma, and by students who have undergone similar requirements (Transcripts, 2017). However, it should be noted that the practical management of legal education in Germany is slightly different. It includes two steps: University learning (Studium) and 2year practice (Referendariat). Each of these steps leads to the completion of the national exam (Staatsexamen) after each step (Svistunov, Šepanskij, \& Kulikova, 2016, p.54). According to comparative research done by European Commission on Lawyers training system in European Union, in Germany no university degree is necessary to enter the profession of lawyer, but law students must sit an exam in law organized by the State only after completing their university studies (4 years). The part of the exam dealing with a specialized area of law (chosen by the participants) is organized and carried out by the university; it counts $30 \%$, but in practice more attention is paid to the marks obtained in the State exam in the obligatory areas of law (Lawyers training systems in the EU, 2014). Statistics show that the exam in Germany is very complicated: $30 \%$ of students are not able to pass the first exam; but $20 \%$ of students do not pass the second exam(Svistunov, Šepanskij, \& Kulikova, 2016, p.55).

Also specific features of the German state must be taken into account: Germany consists of 16 Federal States, each one has its own legal basis with differences mainly as to the length of the parts spent at different professions. At Federal level it is regulated by German Judiciary Act (German Judiciary Act, 1972). Article 5a of the mentioned Act prescribes that University studies shall last for four years; this period may be of shorter duration in so far as the requisite attainments for admission to the university examination covering areas of specialisation and to the state examination covering compulsory subjects are demonstrated. The course of studies comprises compulsory subjects and areas of specialisation with elective subjects. In addition, proof is required of the successful completion of a law course in a foreign language or a language course geared specifically to law; provision may be made under Land law that proof of foreign language skills can be provided in another manner. Compulsory subjects shall comprise the core areas of civil law, criminal law, public law and the law of procedure, including the links with European law, the methodology of legal science and the philosophical, historical and social foundations. The areas of specialisation serve to supplement university studies, to deepen knowledge of the compulsory subjects to which they relate, and to impart the interdisciplinary and international bearing of the law. The programme of studies shall cover the practice in court adjudication, in the administration and in legal advice, including the key qualifications required therefor, such as negotiation management, negotiation skills, rhetoric, conciliation, mediation, questioning techniques and communication skills (German Judiciary Act, 1972, Article 5a). 
After completion of the legal traineeship, the candidate must take the 2nd State Examination. The failure rate is far less than in the 1st State Examination. The written part consists of drafting judgments, accusations, letters of lawyers in legal procedures or contract drafts for legally challenging cases presented in the form of short acts. After passing successfully the 2nd State Exam, the trainee may become a fully-fledged lawyer (Lawyers training systems in the EU, 2014).

One difference between Latvia and Germany relates also to content of the Examination. In Germany, the syllabus for the university examination covering areas of specialisation and for the state examination covering compulsory subjects shall be so designed as to enable university studies to be completed after fourand-a-half years of study. The university examination covering areas of specialisation must include at least one written assignment. The state examination covering compulsory subjects must comprise both written assignments and oral examinations (German Judiciary Act, 1972, Subarticle (2) of the Article 5d). In Latvia, the qualification examination shall examine the knowledge and skills of the student in the following fields:

1. criminal and criminal proceedings rights;

2. civil law, civil proceedings law and commercial law;

3. constitutional law, administrative law and administrative proceedings law;

4. international and European Union law;

5. the theory of law, the philosophy of law and the history of law in Latvia (Valsts vienotā jurista profesionālās kvalifikācijas eksāmena kārtība, 2019, article 24). Question in this case is the following: so, study programmes of all universities in Latvia must become uniform without any specialization? Also we are faced with a new approach to the planning of study courses, which in general might not have to be judged negatively, but will have a very specific impact on the autonomy of universities concerning the syllabus of the study courses.

From the existing legal regulation it is also unclear what the criteria are, the content of which the requirements will be specified for the methodology for evaluating the Examinaton, which is approved by the Examination commission itself. This could be a risk element for transparency and uniform understanding during the development of examination questions and in the evaluation process of Examination answers. Dean of the Law faculty of University of Latvia Anita Rodina also pointed out that it has been worked on for a long time: "How this will work in practice can only be seen in theory at this time. I think there will be a lot of confusion and questions for the chairman of the Examination commission initially, and also for the members. It could be said that working on the commission in at least the first few years would be a challenge for every member 
of the commission. In this case, those who have had experience in conducting such closing examinations will have an advantage. (Krūzkopa, 2019)."

Table 1 Comparision of Uniform Examination

\begin{tabular}{|c|c|c|}
\hline Component of Comparision & Latvia & Germany \\
\hline Territory comprised & Unitary examination & $\begin{array}{c}16 \text { different examinations } \\
\text { for each Federal Land }\end{array}$ \\
\hline When Examination is done & After Master's degree & $\begin{array}{c}\text { Two state National } \\
\text { Examinations: after } \\
\text { University learning and 2- } \\
\text { year practice }\end{array}$ \\
\hline Contents of the Exam & Compulsory fields & $\begin{array}{c}\text { Compulsory fields + } \\
\text { specialization }\end{array}$ \\
\hline
\end{tabular}

Source: made by author of the article.

No doubt universities are preparing for Examination; it means also to change the content of a rather stable study process and study courses. For example, professional master study programme of the Law Faculty of Riga Stradiňs university will need to include partly content what has already been done in the bachelor's programme study courses, adding topical legal problems, with a wider use of the case studies. Specialisation courses will probably reduced by numbers, if not any changes in the existing regulation.

\section{Conclusions}

1. The research aim of the present article is to analyse critically the new regulation on procedures for the Examination have been achieved from the author's point of view. Author agrees with A. Gaveika and K. Bite that the idea of a single Examination must be supported as it will increase the quality of the profession of the lawyer.

2. Efforts to raise the quality of legal education and the knowledge and skills of law-school graduates through an Examination are very interesting, but at the same time it is also a complicated experiment. It is necessary to develop a testing methodology setting out clear criteria, content and requirements for the assessment approach of the Examination.

3. The Examination is intended after the acquisition of a master's study programme (for the acquisition of qualifications), but the knowledge and skills to be tested, are fundamental issues of law which usually studied in bachelor programme. Such a system does not allow you to verify the quality of the studies, since the bachelor's programme can be learned in other universities, or it may be long period after graduation of the bachelor's 
programme, etc. Therefore the author proposes to divide Examination into two examinations: one after the bachelor programme, one after the Master programme. This will be more similar system to the uniform examination system in Germany.

4. The areas of law covered where a student shall have to pass an Examination do not include specialisation study courses of individual university, for example, like medical law or operative law at Riga Stradiņš university. I assume that one part the Examination (not more than 30\%) must consist of theory and practise in connection with law specialisation of the particular university.

5. It is not clear what the criteria are, the content of what the requirements will be for the methodology for evaluating the Examination, which is approved by the commission itself. This could be a risk element for transparency and uniform understanding during the development of examination questions and in the evaluation process of examination answers.

6. Specific questions of the Examination in Latvia shall be determined by the chairperson of the commission, the vice-chairperson of the commission and the representatives of the industry from the Prosecutor General's Office and the professional organisations representing the legal sector. I propose that also representatives from universities must be included in the process of determination of questions as academic persons have better focus on the content of study programmes.

7. At the moment, it is too early to conclude whether the introduction of an Examination will indeed raise the quality of legal education and increase the knowledge and skills of graduates in law. The first Examinations will show other practical problems even not covered in the article.

\section{References}

Bite, K. (2018). The problems of legal regulation for obtaining of lawyer's qualification in Latvia. Thesis of the conference. Retrieved from https://congress.sciencelatvia.lv/wpcontent/uploads/sites/89/2018/05/Visas-t\%C4\%93zes-m\%C4\%81jaslapai.pdf

Gaveika, A. (2018). Trends of Legal Education Reform in Latvia. Society. Integration. Education. Proceedings of the International Scientific Conference. Volume I, 113-123.

Gaveika, A. (2017). Vienotais jurista eksāmens, par un pret. 11. Starptautiskā zinātniskā konference „Sabiedrība. Integrācija. Izglītība”, 152 - 160.

German Judiciary Act (1972). Retrieved from http://www.gesetze-im-internet.de/ englisch_drig/englisch_drig.html\#p0032

Krūzkopa, S. (2019). Juristu profesionālās kvalitātes eksāmens joprojām raisa jautājumus. Latvijas Vēstnesis, 2019.gada 25.janvārī. Pieejams https://lvportals.lv/norises/301577juristu-profesionalas-kvalitates-eksamens-joprojam-raisa-jautajumus-2019

Latvijas Republikas 12.Saeimas pavasara sesijas 2017.gada 20.aprịla stenogramma (Transcripts, 2017). Pieejams https://www.saeima.lv/lv/transcripts/view/414 
Lawyers training systems in the EU (2014). European Commission. Retrieved from file:///C:/Users/jangra/Downloads/Germany_factsheet_v3_web_EU_en\%20(3).pdf

Medina, L., \& Salinieka, I. (2020). Juridiskās izglītības kvalitāte. Kurp ejam? Jurista vārds, 1, 07.01.2020., 40-43.

Ministru kabineta 2019. gada 15. janvāra noteikumi Nr. 46 "Valsts vienotā jurista profesionālās kvalifikācijas eksāmena kārtība”. Pieejams https://likumi.lv/ta/id/304369-valsts-vienotajurista-profesionalas-kvalifikacijas-eksamena-kartiba

Načisčionis, J. (2019). Labi un kvalificēti juristi ir un būs nepieciešami vienmēr. Ir, 2019.gada 18.jūlijā

Parlaments atbalsta vienota juristu kvalifikācijas eksāmena ieviešanu. (2017). Pieejams https://www.e-klase.lv/aktualitates/zinas/parlaments-atbalsta-vienota-juristukvalifikacijas-eksamena-ieviesanu?id=11484

Svistunov, A., Šepanskij, I., \& Kulikova, T. (2016). Zarubeznij i otecestvennij opit ocenki kvalifikaciji juristov. Moskva, Izdatelstvo Norma.

Vilks, A. (2019). New challenges for legal education. Socrates. Electronic Scientific Journal of Faculty of Law of Rìga Stradiņš University, 2(14), 53-62. 